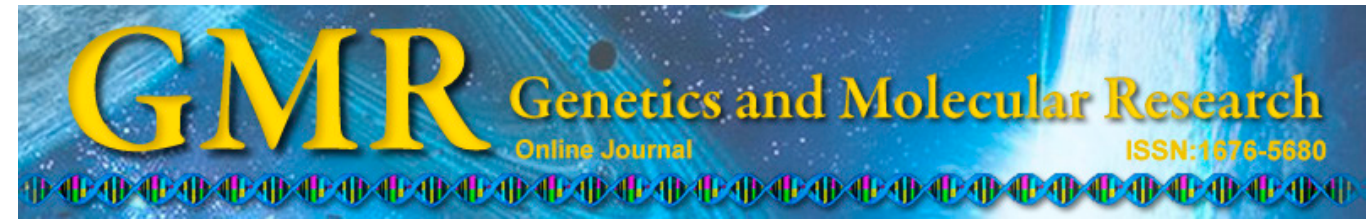

\title{
Application of SCAR markers linked with mungbean yellow mosaic virus disease-resistance gene in Pakistan mungbean germplasm
}

\author{
R. Binyamin', M.A. Khan ${ }^{1}$, N.A. $\operatorname{Khan}^{1}$ and A.I. Khan ${ }^{2}$ \\ ${ }^{1}$ Department of Plant Pathology, University of Agriculture, \\ Faisalabad, Pakistan \\ ${ }^{2}$ Department of Plant Breeding and Genetics, University of Agriculture, \\ Faisalabad, Pakistan \\ Corresponding author: R. Binyamin \\ E-mail: binyamin1388@gmail.com
}

Genet. Mol. Res. 14 (1): 2825-2830 (2015)

Received March 10, 2014

Accepted September 25, 2014

Published March 31, 2015

DOI http://dx.doi.org/10.4238/2015.March.31.13

\begin{abstract}
Mungbean yellow mosaic virus disease (MYMVD) caused by single-stranded DNA begomovirus is the most prominent threat to the mungbean crop in Pakistan. Mungbean genotypes consisting of 127 varieties/lines were screened for MYMVD under natural field conditions. No genotypes were found to be immune or highly resistant against MYMVD. Genotypes showing resistant and tolerant responses in field screening trials were screened using sequence characterized amplified region (SCAR) markers linked with the MYMVD-resistance gene. SCAR markers amplified the desired band only in the resistant and tolerant genotypes, while no amplification was observed in susceptible genotypes. SCAR markers will be useful for future breeding and varietal developmental programs and mungbean genotypes can be screened on the molecular level.
\end{abstract}

Key words: Germplasm; Mungbean yellow mosaic virus disease; Mungbean; Sequence characterized amplified region 


\section{INTRODUCTION}

Mungbean is an important pulse crop grown worldwide. Mungbean yellow mosaic virus is a destructive virus that causes severe yield losses of mungbean crops. Mungbean yellow mosaic virus belongs to family Geminiviridae and genus Begomovirus (Bos, 1999). Mungbean yellow mosaic virus disease (MYMVD) also infects other legume crops, including urdbean, soybean, and cowpea (Dhingra and Chenulu, 1985; Qazi et al., 2007). This disease causes severe destruction of legume crops in Pakistan, Srilanka, India, and Bangladesh (Bakar, 1981; Malik, 1991; Biswass et al., 2008; John et al., 2008). MYMVD causes more than US\$300 million loss every year in different leguminous crops (Varma et al., 1992). Legume crops are severely affected by different viral diseases (Binyamin et al., 2011b). Screening of mungbean for MYMVD to identify a resistance source under natural field conditions has been reported in different studies (Bashir and Zubair, 2002; Shad et al., 2006; Pandiyon et al., 2007).

Epidemics caused by MYMVD have been attributed to their frequent recombination and transmission caused by Bemisia tabaci. Management of MYMVD is often linked with control of the $B$. tabaci population, which is sometimes ineffective because of high population pressure. Therefore, the most economical, efficient, and environmentally friendly method for managing this disease is host resistance (Binyamin et al., 2011a). Molecular markers have been applied in studies of various traits that are time saving and more authentic then field-screening results. Several previous studies have reported that resistance in mungbean to MYMVD is conferred by a single recessive gene (Singh and Patel, 1977; Thakur et al., 1977; Reddy and Singh, 1995; Basak et al., 2004). In mungbean, sequence characterized amplified region (SCAR) markers are reportedly linked with MYMVD-resistance gene. Souframanien and Gopalakrishna (2006) reported an SCAR marker linked with the resistance gene against MYMVD in blackgram. In earlier studies, randomly amplified polymorphic DNA was used to identify the mungbean yellow mosaic virus-resistance gene in mungbean germplasm, either directly or after conversion into SCAR markers (Selvi et al., 2006; Chen et al., 2007) and in a number of other crops such as blackgram (Souframanien and Gopalakrishna, 2006), soybean (Zheng et al., 2003), and common beans (Alzate-Marin et al., 1999). Molecular markers linked with resistance genes have been reported for different viral diseases (Urrea et al., 1996; Marczewski et al., 2001; Zheng et al., 2003; Gao et al., 2004). Some genotypes were resistant, while some were found to be tolerant or susceptible at another location. This might be due to break down of host-resistance mutation of the pathogen or both; therefore, there is a strong need for regular, careful and thorough screening of mungbean germplasm for identification of resistant source. After resistance source identification and molecular markers associated with resistance gene there would be rapid increase in selection authenticity and efficiency. A reasonable method for controlling viral diseases is the use of resistant crop varieties. Studies have been examined to evaluate mungbean accessions against MYMVD to identify resistant sources under natural field conditions.

\section{MATERIAL AND METHODS}

\section{Plant material}

A total of 127 mungbean genotypes were screened against MYMVD for 2 years, 2012 and 2013. Of these, 15 mungbean genotypes were selected based on their resistance, tolerance and susceptible response in the field against MYMVD. Field-screening results were validated 
using 2 SCAR markers linked with MYMVD as previously reported in mungbean and blackgram. Seeds of mungbean genotypes were sown in pots (Table 1). Fresh leaf samples (8-10) from potted mungbean plants were collected 1 week after germination and DNA from these samples was immediately extracted following a CTAB method, with certain modifications (Doyle and Doyle, 1990).

\begin{tabular}{lll}
\multicolumn{2}{c}{ Table 1. Mungbean genotypes used for SCAR markers. } \\
\hline Sample No. & Varieties/lines & Resistance level \\
\hline 1 & NM-2011 & Resistant \\
2 & NM-2006 & Resistant \\
3 & Azri-06 & Resistant \\
4 & NM-92 & Moderately resistant \\
5 & C2 $94-4-36$ & Moderately resistant \\
6 & NM121-25 & Moderately resistant \\
7 & 07007 & Moderately resistant \\
8 & 98001 & Moderately resistant \\
9 & 014322 & Moderately resistant \\
10 & 014328 & Moderately resistant \\
11 & 014527 & Moderately resistant \\
12 & 014532 & Moderately resistant \\
13 & M-6 & Highly susceptible \\
14 & 8010 & Highly susceptible \\
15 & 8011 & Highly susceptible \\
\hline
\end{tabular}

\section{DNA extraction}

A preheated $2 \mathrm{X} \mathrm{CTAB}$ solution in a water bath at $65^{\circ} \mathrm{C}$ was prepared. Leaf samples were ground in liquid nitrogen to a fine powder and then transferred to test tube; $15 \mathrm{~mL}$ CTAB was added, mixed gently, and incubated at $65^{\circ} \mathrm{C}$ for $30 \mathrm{~min}$. Next $15 \mathrm{~mL}$ chloroform/isoamylalcohol (24:1) was added and centrifuged for $10 \mathrm{~min}$ at $2716 \mathrm{~g}$. The supernatant was transferred to a new test tube and 0.6 vol. chilled propanol was added, and the tube centrifuged at $9000 \mathrm{rpm}$ for $5 \mathrm{~min}$. The pellet was washed with ethanol, and air dried, and dissolved in 500 $\mu \mathrm{L} \mathrm{d}_{3} \mathrm{H}_{2} \mathrm{O}$. This suspension was transferred to a microcentrifuge tube, $5 \mu \mathrm{L}$ RNase was added and, the sample was incubated for $1 \mathrm{~h}$ at $37^{\circ} \mathrm{C}$. An equal vol. chloroform/isoamylalcohol was added and centrifuged at 13,000 rpm for $10 \mathrm{~min}$. The supernatant was placed in a new microcentrifuge tube and vol. 1/10th $\mathrm{NaCl}$ was added along with a double-volume chilled ethanol followed by centrifugation at $13,000 \mathrm{rpm}$ for $10 \mathrm{~min}$. The pellet was washed with $70 \%$ ethanol, and air dried, and dissolved in $\mathrm{d}_{3} \mathrm{H}_{2} \mathrm{O}$.

\section{DNA quantification}

The genomic DNA concentration of mungbean germplasm was quantified using a spectrophotometer (CE 2021, Cecil Instruments, Cambridge, UK). The optical density of each sample was calculated by measuring the absorption at $260 \mathrm{~nm}$. Three different dilutions (15, 20 , and $25 \mathrm{ng} / \mu \mathrm{L}$ ) from the stock DNA samples were prepared to optimize the DNA concentration for the best amplification.

\section{Primer sequence of SCAR markers}

Two SCAR markers linked with MYMVD were used, 1 reported in mungbean and 
other reported in blackgram, to amplify the genomic DNA in the varieties/lines selected after field screening (Table 2).

Table 2. Detail of SCAR primers along with their sequences used in this study.
\begin{tabular}{lll}
\hline Sr. No. & Marker name & Sequence \\
\hline 1 & MYMVR-583 (SCAR) & F: GTGATGCACACGGTTACGGT \\
2 & R: GGTGACGCAGTCCATACAAATTT \\
& YMV1 (SCAR) & F: GAGAGAGAGAGAGAGACAAAG \\
\hline
\end{tabular}

\section{PCR conditions for SCAR markers}

The total reaction was performed in a volume of $20 \mu \mathrm{L}$. The $20-\mu \mathrm{L}$ reaction mixture included $2 \mu \mathrm{L}$ genomic DNA, $0.2 \mu \mathrm{L}$ Taq DNA polymerase (MBI, Fermentas, Vinius, Lithuania), $2 \mu \mathrm{L} 10 \mathrm{X}$ buffer, $1.6 \mu \mathrm{L} \mathrm{MgCl}_{2}(2.5 \mathrm{mM}), 6.4 \mu \mathrm{L}$ dNTPs $(0.4 \mathrm{mM}), 1 \mu \mathrm{L}$ of each primer $(5 \mu \mathrm{M})$, and $5.8 \mu \mathrm{L} \mathrm{d}_{3} \mathrm{H}_{2} \mathrm{O}$. PCR amplification was performed as follows; initial denaturation at $94^{\circ} \mathrm{C}$ (for $4 \mathrm{~min}$ ), followed by 35 cycles of denaturation at $94^{\circ} \mathrm{C}$ for $30 \mathrm{~s}$, primer annealing at $64^{\circ} \mathrm{C}$ for $1 \mathrm{~min}$, extension at $72^{\circ} \mathrm{C}$ for $1 \mathrm{~min}$, and a final extension at $72^{\circ} \mathrm{C}$ for $7 \mathrm{~min}$.

\section{RESULTS}

Two SCAR markers were previously reported to be linked with the MYMVDresistance gene. Fifteen mungbean genotypes showing resistant, moderately resistant, moderately susceptible, and highly susceptible responses in the field screening were selected to evaluate whether contained the reported resistance gene or other which conferred resistance to MYMVD. Presence or absence of SCAR markers in diverse mungbean germplasm was investigated. Twelve genotypes showed amplification with both SCAR markers, indicating that they contained the MYMVD-resistance gene (Figures 1 and 2). Three genotypes that were highly susceptible to MYMVD in the field screening also showed the same results and no amplification were observed in these 3 genotypes. SCAR markers were consistently present in all genotypes reported to be resistant and moderately resistant in the field-screening results and absent in all genotypes showing a highly susceptible response.

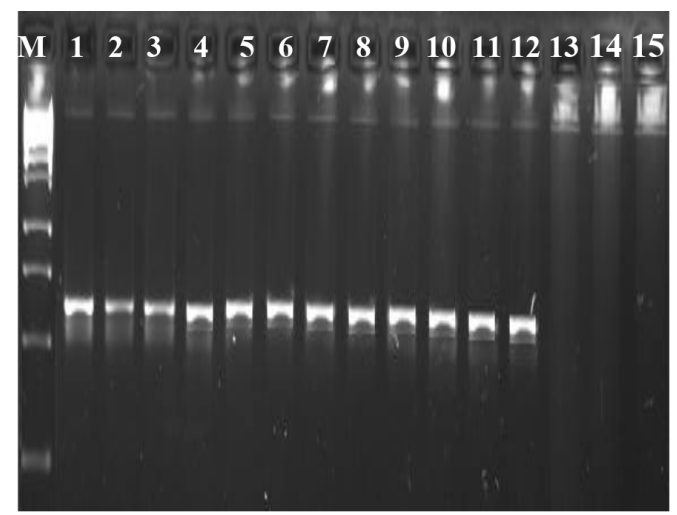

Figure 1. SCAR-PCR with primer MYMVR-583. Lanes 1-15 = genotypes; lane $M=1-\mathrm{kb}$ ladder. 


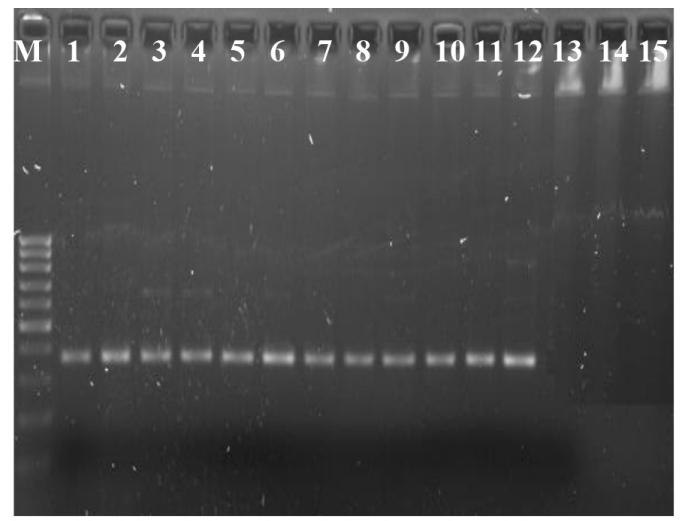

Figure 2. SCAR-PCR with primer YMV1. Lanes 1-15 = genotypes; lane $M=50$-bp ladder.

Many commercial mungbean cultivars are susceptible to MYMVD; therefore, a marker closely linked with the MYMVD-resistance gene has increased. A resistance gene that can be transferred to cultivars with excellent potential yield by using the marker-assisted breeding would be beneficial. Breeding programs based on phenotypic and symptomatic analysis are very time consuming, while the use of molecular markers for resistance breeding is a more rapid process. Marker behavior was examined using marker validation and for associated polymorphisms present in genotypes with different genetic backgrounds (Gupta et al., 1999).

The most important requirement for marker-assisted selection is the correct identification of a marker linked to a specific or desired trait and its efficiency for screening a large number of genotypes in a reproducible manner. Screening of mungbean genotypes was performed based on different DNA markers linked with the MYMVD-resistance gene, which have been reported in mungbean (Dhole and Reddy, 2013) and blackgram (Souframanien and Gopalakrishna, 2006). A single recessive gene for MYMVD resistance has been reported in mungbean in several previous studies (Singh and Patel, 1977; Thakur et al., 1977; Reddy and Singh, 1995; Basak et al., 2004). One SCAR marker was reported to be linked with the mungbean yellow mosaic virus-resistance gene in mungbean and the second was reported to be linked with mungbean yellow mosaic virus-resistance gene in blackgram. The SCAR marker (MYMVR-583) amplified a single band of 583 bp in all 12 genotypes reported to be resistant and moderately resistant, while no amplification was observed in highly susceptible genotypes. Therefore, the marker was considered to be a dominant marker for the recessive allele conferring resistance to MYMVD. Dhole and Reddy (2013) identified and used an SCAR marker (MYMVR-583) for mungbean screening against MYMVD; the results of the present study agreed with those of previous studies and SCAR primers produced bands of the same size as predicted. Similarly, a second SCAR marker (YMV1) amplified a band in resistant and moderately resistant genotypes and no fragment was observed in highly susceptible genotypes, indicating that they lack the resistance gene, causing highly susceptible response. Validation of SCAR markers showed positive results, and indicates consistent association of markers with the genotypes having resistant response in field, while, no amplified band was observed in three genotypes showing highly susceptible response in the field. These SCAR markers will increase the efficiency and accuracy in MYMVD-resistance breading programm and could be used in future breeding program for the development of mungbean yellow mosaic virus disease-resistance cultivars with high yield. 


\section{REFERENCES}

Alzate-Marin AL, Menarim H, de Carvalho GA, de Paula TJ, et al. (1999). Improved selection with newly identified RAPD markers linked to resistance gene to four pathotypes of $C$. lindemuthianum in common beans. Phytopathology 89: 281-285.

Bakar AK (1981). Pest and disease problems of mung bean in west Malaysia. Malay. J. Agric. 53: 29-33.

Basak J, Kundagrami S, Ghose TA and Pal A (2004). Development of yellow mosaic virus (YMV) resistance linked DNA marker in Vignamungo from population segregating for YMV reaction. Mol. Breed. 14: 375-383.

Bashir M and Zubair M (2002). Identification of resistance in urdbean (Vigna mungo) against two different viral diseases. Pak. J. Bot. 34: 49-51.

Binyamin R, Khan MA, Khan AI, Khan MA, et al. (2011a). Molecular characterization of urdbean (Vigna mungo) germplasm related to resistance against urdbean leaf crinkle virus. Genet. Mol. Res. 10: 1681-1688.

Binyamin R, Khan MA, Ahmad N and Ali S (2011b). Relationship of epidemiological factors with urdbean leaf crinkle virus disease and its management using plant extracts. Int. J. Agric. Biol. 13: 411-414.

Biswass KK, Malathi VG and Varma A (2008). Diagnosis of symptomless yellow mosaic begomovirus infection in pigeon pea by using cloned mungbean yellow mosaic India virus a probe. J. Plant Biochem. Biotechnol. 17: 9-14.

Bos L (1999). Plant Viruses: Unique and Intriguing Pathogens: A Text Book of Plant Virology, Backhuys Publishers, Leiden.

Chen HM, Chien AL, Kuo CG, Chien CM, et al. (2007). Development of a molecular marker for a bruchids (Callosobruchus chinensis L.) resistance gene in mungbean. Euphytica 157: 113-122.

Dhingra KL and Chenulu VV (1985). Effect of yellow mosaic on yield and nodulation of soybean. Indian Phytopathol. 38: 248-251.

Dhole VJ and Reddy KS (2013). Development of a SCAR marker linked with a MYMV resistance gene in mungbean (Vigna radiata L. Wilczek). Plant Breed. 132: 127-132.

Doyle JJ and Doyle JL (1990). Isolation of plant DNA from fresh tissue. Focus 12: 13-15.

Gao Z, Eyers S, Thomas C, Ellis N, et al. (2004). Identification of markers tightly linked to sbm recessive genes for resistance to pea seed-borne mosaic virus. Theor. Appl. Genet. 109: 488-494.

Gupta PK, Varshney RK, Sharma PC and Ramesh B (1999). Molecular markers and their application in wheat breeding. Plant Breed. 118: 369-390.

John P, Sivalingam PN, Haq QMI and Kumar N (2008). Cowpea golden mosaic disease in Gujrat is caused by a mungbean yellow mosaic India virus isolate with a DNA B variant. Arch. Virol. 153: 1359-1365.

Malik JA (1991). Breeding for Resistance to MYMV and its Vector in Pakistan. Mungbean YMDs. Proceedings of an International Workshop (Green SK and Kim D, eds.). Bangkok, Thailand, July 23, 1991. AVRDC, 41-53.

Marczewski W, Talarczyk A and Hennig J (2001). Development of SCAR markers linked to the Ns locus in potato. Plant Breed. 120: 88-90.

Pandiyon M, Subbalakshmi B, Alice D and Marimethn R (2007). Screening of mungbean (Vigna radiata (L.) Wilczek) germplasm for mungbean yellow mosaic virus. Plant Arch. 7: 375-376.

Qazi J, Ilyas M, Mansoor S and RW Briddon (2007). Legume yellow mosaic viruses: genetically isolated begomoviruses. Mol. Plant Pathol. 8: 343-348.

Reddy KR and Singh DP (1995). Inheritance of resistance to mungbean yellow mosaic virus. Madras Agric. J. 88: 199-201.

Selvi R, Muthiah AR, Manivannan N, Raveendran TS, et al. (2006). Tagging of RAPD marker for MYMV resistance in mungbean (Vigna radiata L. Wilczek). Asian J. Plant Sci. 5: 277-280.

Shad N, Mughal SM, Farooq K and Bashir M (2006). Evaluation of mungbeen germplasm for resistance against mungbean yellow mosaic Begomovirus. Pak. J. Bot. 38: 449-457.

Singh D and Patel PN (1977). Studies on resistance in crops to bacterial diseases in India. III. Investigations on inheritance of reactions to bacterial leaf spot and yellow mosaic diseases and linkage, if any, with other characters in mungbean. Indian Phytopathol. 30: 202-206.

Souframanien J and Gopalakrishna T (2006). ISSR and SCAR marker linked to the mungbean yellow mosaic virus (MYMV) resistance gene in blackgram (Vigna mungo L. Hepper). Plant Breed. 125: 619-622.

Thakur RP, Patel PN and Verma JP (1977). Genetical relationship between reaction to bacterial leaf spot, yellow mosaic and Cercospora leaf spot diseases in mungbean (Vigna radiata L. Wilczek). Euphytica 26: 765-774.

Urrea CA, Miklas PN, Beaver JS and Riley RH (1996). A codominant RAPD marker useful for indirect selection of BGMV resistance in common bean. J. Am. Soc. Hort. Sci. 121: 1035-1039.

Varma A, Dhar AK and Mandal B (1992). MYMV Transmission and Control in India. In: Mungbean Yellow Mosaic Disease (Green SK and Kim D, eds.). Asian Vegetable Research and Development Centre, Taipei, 8-27.

Zheng C, Chang R, Qiu L, Chen P, et al. (2003). Identification and characterization of a RAPD/SCAR markers linked to a resistance gene for soybean mosaic virus in soybean. Euphytica 132: 199-210. 